\section{Pre-Scarification and Strip Clearcutting to Obtain Lodgepole Pine Regeneration}

\author{
by $H$. J. Johnson
}

\begin{abstract}
In 1952 an experiment was conducted near Strachan in the lower foothills of Alberta in a study of regeneration of lodgepole pine (Pinus contorta Dougl. var. latifolia Engelm.) obtained by pre-scarification and strip clearcutting. The results to 1968 support this technique, regeneration on pre-scarified areas having exceeded 80 per cent stocking. Height growth of the tallest seedlings on scarified areas was over 50 per cent greater than those on undisturbed areas.
\end{abstract}

\section{Extrait}

En 1952, près de Strachan, sis sur les premiers contreforts des Rocheuses en Alberta, on a étudié la régénération du Pin de Murray (Pinus contorta Dougl. var. latifolia Engelm.) à la suite de préscarifiages et de coupes à blanc par bandes. Le pré-scarifiage s'est révélé très efficace puisqu'en 1968, la régénération a couvert $80 \%$ de la superficie ainsi traitée et que la croissance y était de $50 \%$ plus forte que dans les bandes coupées à blanc mais non scarifiées.

In 1952, Crossley established an experiment to study regeneration after pre-scarifying and strip clearcutting in a stand of lodgepole pine near Strachan, Alberta. The preliminary results and tentative conclusions reported by him (Crossley, 1956) were extremely promising. However, it is not uncommon for early success in regeneration trials to be followed by excessive mortality or poor growth. Therefore, re-measurements and appraisals of the study were made in 1962 and 1968. This report confirms Crossley's earlier findings and presents new information with respect to stocking and tree growth.
Forestry Officer,

Department of Forestry and

Rural Development

Colgory, Alberta.

Oxf. $221.22 \quad 231.331$

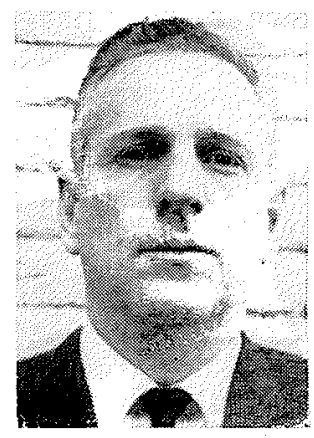

\section{Methods}

This study was conducted in an 85-year old stand of lodgepole pine situated in the Lower Foothills Section of the Boreal Forest Region (Rowe, 1959) near Strachan, Alberta. According to Crossley (1956), the physiographic site is classified (Hills, 1952) as " $4: 1: 3 / 1$, i.e., the local climate is standard, the soil moisture regime is somewhat dry, and the material permeability somewhat rapid through the surface deposit of silt loam and very rapid through the underlying coarse-textured outwash material".

A complete description of methods is presented by Crossley (1956). Briefly the following was done.

Eight 1.2-acre units ( 6 chains in length and 2 chains wide) were established in 1952 . The following four treatments were replicated and assigned randomly to the units:

1. Forest floor unscarified - slash lopped and scattered.

2. Forest floor unscarified - slash removed by piling and burning.

3. Forest floor scarified - slash lopped and scattered.

4. Forest íloor scarified - slash removed by piling and burning.

Scarification was done in June 1952 prior to clearcutting with a small tractor and the resulting degree of scarification, on an area basis, averaged 19.5 per cent scarified, 55.2 per cent disturbed and 25.3 per cent undisturbed (Crossley 1956). Logging commenced during the winter of 1952-53 and was completed the following spring. Where applicable, slash was lopped and scattered at the time of logging.

The objective of removing slash by piling and 


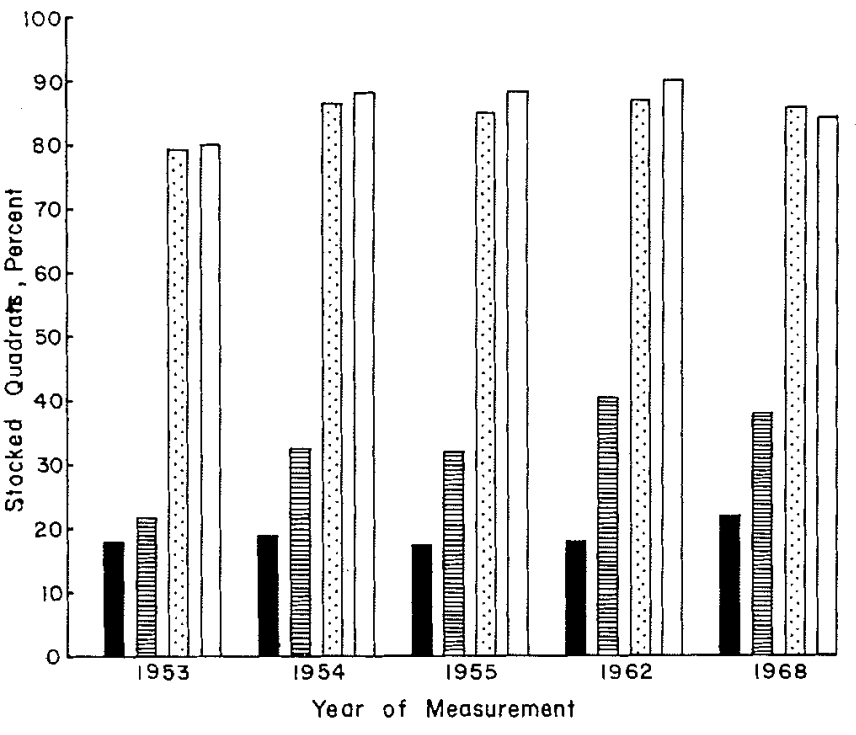

$\because \because$ Scarified, Lopped a Scallered
$\square$ Scarified, Piled a Burned
Unscorified, Lopped a Scoltered
Unscorified, Piled a Burned

FIGURE I. PERCENT STOCKING ON VARIOUS TREATMENTS

burning was to eliminate seed from slash-borne cones in an attempt to assess availability of seed from residual stands. It soon became apparent that all seed from this source could not be removed even by handpicking cones on sample quadrats established for future regeneration studies.

Regeneration on the various treatment units was tallied in 1953, 1954, 1955 and 1962 on contiguous, permanent, one mil acre quadrats in lines spaced at 1 chain intervals across the cut strips. The height of the tallest seedling in each quadrat was measured in 1955, 1956, 1962 and 1968. The presence or absence of seedlings on the sample quadrats in 1968 was noted.

\section{RESULTS}

\section{Stocking}

The excellent stocking on scarified areas was maintained to 1968 (Fig. 1). A small number of seedlings continued to germinate after 1954. However, most of the seedlings present in 1962 originated during the first two years after logging.

The stocking of seedlings on scarified areas was not appreciably different regardless of whether slash was lopped and scattered or piled and burned. However, where the forest floor was left unscarified and the slash piled and burned, per cent stocking increased approximately twofold between 1953 and 1968. No increase in percentage stocking occured where the slash was lopped and scattered.

Table 1 shows the number of seedlings per acre on the various treatment areas in 1953, 1954, 1955

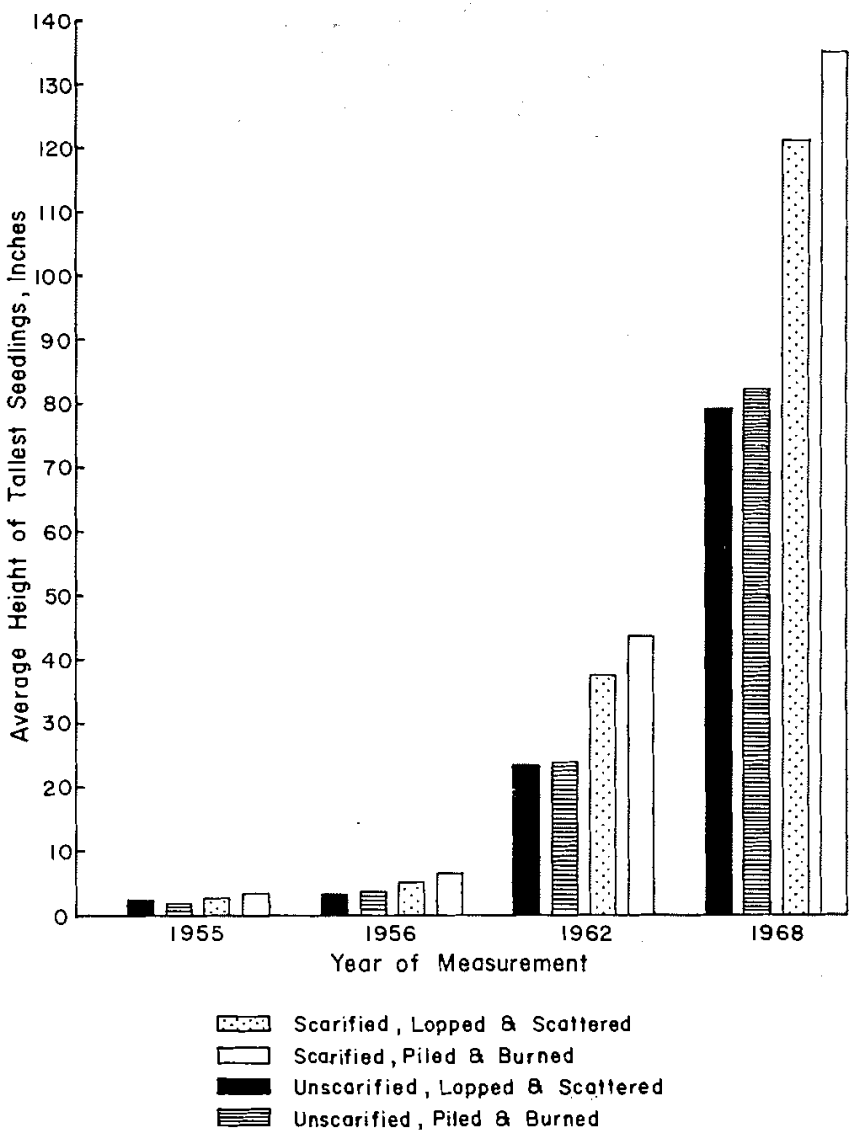

FIGURE 2, AVERAGE HEIGHT OF TALLEST SEEDLINGS ON VARIOUS TREATMENTS.

and 1962. Density of stocking was not measured in 1968. The difference between the number of trees per acre on scarified and unscarified areas is appreciable. On both scarified and unscarified areas the numbers of seedlings per acre were higher where slash was piled and burned.

Table 1. NUMBER OF LODGEPOLE PINE SEEDLINGS
PER ACRE.

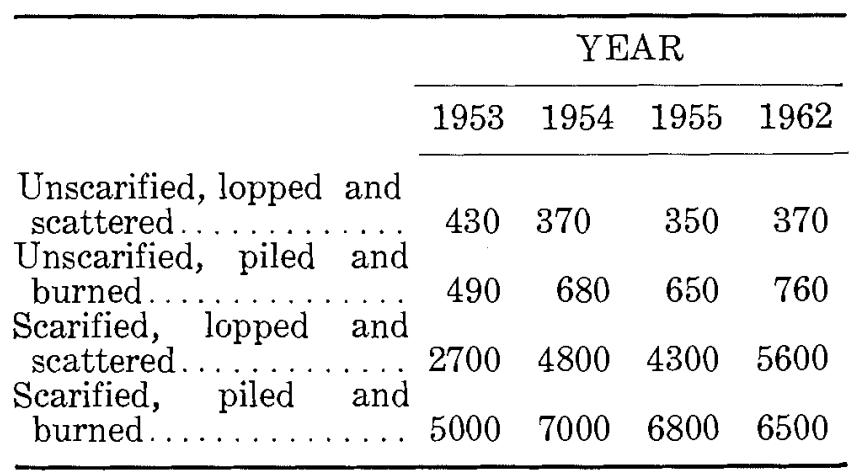

\section{Height Growth}

During 1955, 1956, 1962 and 1968 the tallest seedlings growing on scarified units were, on the average, 45, 59, 67 and 57 per cent taller respectively than those growing on unscarified units. This trend suggests a decrease in differential height growth after 1962, however, the difference is still substantial. On scarified areas piling and burning of 


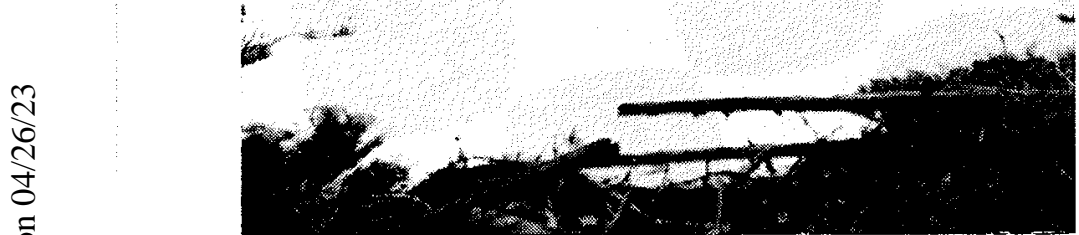

Figure 3 (1968). Block 2 (right) Unscarified, Piled \& Burned. Block 3 (left) Unscarified Lopped \& Scattered.

slash resulted in slightly better height growth than lopping and scattering. On unscarified areas no such effect was apparent. (Fig. 2).

\section{Discussion}

The results of this experiment to 1968 substantiate earlier conclusions reached by Crossley (1956) and support pre-scarification as an effective method of regenerating lodgepole pine stands logged in narrow strips with the slash lopped and scattered or piled and burned. In 1962 regeneration was excellent on scarified areas regardless of the method of slash disposal.

Pre-scarification has advantages over post scarification so far as distribution of cone-bearing slash is concerned. Ackerman (1962) has suggested that post scarification generally results in "a less efficient utilization of the slash-borne seed supply" than prescarification. The importance of slash distribution is not to be ignored in the light of studies conducted by Ackerman (1962) and Crossley (1955). Both show that seed supply from stands bordering cut overs is minimal and that the important seed source is slash-borne cones. Ackerman's study, which covered a five-year period in the Lower Foothills Section of Alberta, indicated an average annual seedfall of only 1,500 sound seeds per acre. This is consistent with Crossley's estimate for the Kananaskis area of 1,200 seeds per acre.

Although it has certain biological advantages over post scarification, pre-scarification may be employed operationally only under special circumstances in lodgepole pine stands at present.

No definite reason can be advanced for the higherpercentage stocking and the number of seedlings per acre on unscarified areas where slash was piled and burned rather than lopped and scattered. It is possible that the burning of small "spots" to mineral soil provided more receptive seedbeds than

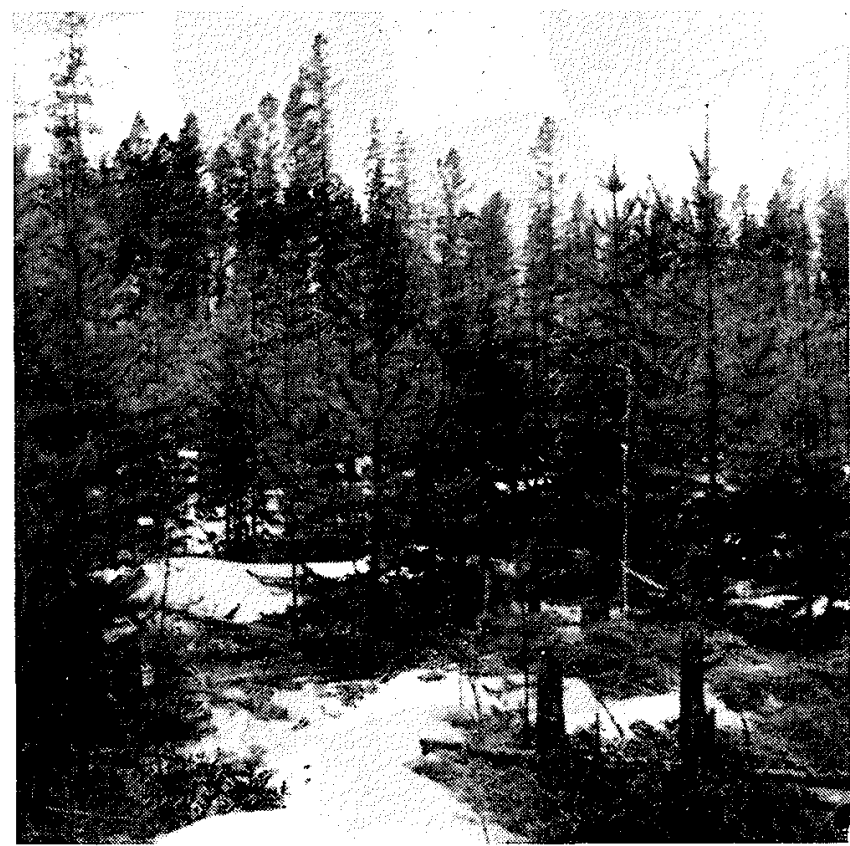

Figure 4 (1968). Block 6. Scarified, Lopped \& Scattered.

those on areas where slash was lopped and scattered. Seed source was probably a combination of marginal stands and seed already on the ground

Another important finding of this experiment is the remarkable difference in the height of the tallest seedlings growing on scarified and unscarified seedbeds. Fifteen years after treatment, lodgepole pine seedlings growing on scarified areas were over 50 per cent taller than seedlings growing on unscarified areas (Figs. 2, 3 and 4). Current research ${ }^{2}$ suggests that better early growth resulting from scarification is largely due to an increase in soil temperatures. This would apply to a scraped-seed bed condition where there is some mixing of organic and mineral soil and not complete removal to the leached layer.

\section{Summary and Conclusions}

An experiment was initiated in 1952 in a study of regeneration obtained by pre-scarifying and strip clearcutting in a lodgepole pine stand near Strachan, Alberta. An effort was made to evaluate marginal stands as a potential seed source.

Conclusions to 1968 are as follow:

1. Pre-scarification is an effective method of seedbed treatment in mature lodgepole pine stands.

2. Pre-scarification has resulted in excellent stocking of lodgepole pine seedlings.

3. Experimental design did not permit assessment of residual stands as a seed source.

4. The presence or absence of cone-bearing slash made very little difference to percentage stocking on scarified areas.

5. On unscarified areas piling and burning the slash resulted in better stocking than lopping and scattering.

6 . For the most part germination of lodgepole

2Discussions with R. F. Ackerman, Research Scientist, Dept. of Forestry and Rural Development, Calgary, Alberta. 
pine seedlings occurred during the first year after treatment.

7. In 1968, the tallest seedlings growing on scar- ified seedbeds were more than 50 per cent taller than the tallest seedlings growing on undisturbed seedbeds.

\section{References}

ACKERMAN, R. F. 1962. Regeneration following strip clearcutting, scarification and slash disposal in a lodgepole pine stand. Canada Dept. Forestry, For. Res. Br., Tech. Note No. 123.

CROSSLEY, D. I. 1955. The production and dispersal of lodgepole pine seed. Canada, Dept. Northern Affairs and National Resources, Forestry Branch. For. Res. Div., Tech. Note No. 25.

CROSSLEY, D. I. 1956. Mechanical scarification and strip clearcutting to induce lodgepole pine regen-

eration. Canada, Dept. Northern Affairs and National Resources, Forestry Branch, For. Res. Div., Tech. Note No. 34.

HILLS, G. A. 1952. The classification and evaluation of site for forestry. Ontario Dept. Lands and Forests, Research Report No. 24.

ROWE, J. S. 1959. Forest regions of Canada. Canada Dept. Northern Affairs and National Resources, For. Br. Bull. 123.

\section{CANADIAN FORESTRY EDUCATION}

To the man interested in Forestry as a career, Canadian schools offer education at all levels.

Professional Training

The four University Forestry Faculties, listed below, offer instruction aimed at understanding of fundamental forestry principles, and training in courses of an applied noture best suited to the needs of the forest regions they serve. Opportunities for post-graduate study are also available at the following: -

\section{University of New Brunswick, Fredericton, N.B. \\ L'Université Laval, Quebec 10, P.Q. \\ University of Toronto, Toronto, Ontario \\ University of British Columbia, Vancouver, B.C.}

Technological and Vocational Training

These courses are designed to provide men with an adequate knowledge of the theory and practice of Forestry, Logging and Milling so that they may, with adequate on-the-job-experience, serve as an intelligent line of communication and action between the professional forester and the forest labourer.

Two year courses in Forest Technology are offered by: -

British Columbia Institute of Technology, Burnaby, B.C.

Cambrian College, Sault Ste. Marie, Ont.

Lakehead University, Port Arthur, Ont.

Nfld. College of Trades and Technology, St. John's, Nfld.

Northern Alberta Institute of Technology, Edmonton, Alta.

Saskatchewan Technical Institute, Saskatoon, Sask.

Sir Sandford Fleming College, Lindsay, Ontario.

One year courses of technical training in Forestry are offered at the following schools: -

B.C. Forest Training School, North Surrey, B.C.

L'Ecole Forestière de Duchesnay, Québec, P.Q.

Maritime Forest Ranger School, Fredericton, N.B.

Ontario Forest Technical School, Dorset, Ontario.

The B.C. and Ontario schools ore limited to in-service training.

For information regarding entrance requirements, courses of study, field training or facilities for specialization at any of the above, please write directly to the school in questions. 